\title{
Laqve (wry mouth) considered in Avicenna's renowned treatise the Canon of Medicine
}

\author{
A. Aciduman; B. Arda*; A. Gunaydin and D. Belen**
}

Ministry of Health Etlik Ihtisas Hospital, Neurosurgery Department. * Department of Medical Ethics and History of Medicine, Ankara University School of Medicine. **Ministry of Health Diskapi Educational and Research Hospital, Neurosurgery Department. Ankara, Turkey.

\section{Summary}

Hemi-facial spasm, facial paralysis, and trigeminal neuralgia are prevailing signs and symptoms with which physicians have been coping for thousands of years. Ibn Sina (known as Avicenna in the West), who was among the leading figures during medieval ages and influenced the upcoming periods in the Eastern and Western hemispheres for long time, focused also on these crucial problems. In his principal medical work, the Canon of Medicine, Avicenna underlined the significance of wry mouth-related disorders and wrote a precise chapter over this topic with the heading "Laqve." However, the term "laqve" is usually accepted only as facial paralysis in most of historical texts. Further detailed analysis of the text reveals that, all the abovementioned signs and symptoms are considered under the same heading. Therefore, the descriptions articulated by famous physician Avicenna pose great merit from the point of historical view of neurological sciences. The main aim of this article is to reintroduce essential parts of the text by adding comments over specific descriptions, and consequently, to make the text more comprehensible for today's scientists.

KEY WORDS: Avicenna. Laqve. Facial paralysis. History of neurosurgery.

Laqve (cara torcida), considerada en el famoso tratado de Avicena: el canon de la Medicina.

\section{Resumen}

Hemiespasmo facial, parálisis facial y neuralgia del trigémino son signos y síntomas a los cuales se han enfrentado los médicos durante milenios. Ibn Sina, (conocido como Avicena en Occidente), que fue una de las figuras más importantes de la Edad Media e influyó tanto en Oriente como en Occidente a lo largo de muchos siglos,

Recibido: 8-04-07. Aceptado: 2-05-07 también prestó gran atención a estos problemas. En su principal trabajo médico, el "Canon de la Medicina", destacó el significado de la "cara torcida" y escribió un capítulo especial sobre estos procesos con el título de "Laqve". Sin embargo, el término "laqve" sólo se acepta como tal, en la mayoría de los textos históricos, cuando se refiere a la parálisis facial. El análisis detallado del texto revela que todos los signos y síntomas mencionados se incluyen en el mismo título. Por consiguiente, las descripciones articuladas por el famoso médico Avicena poseen un gran mérito desde el punto de vista histórico de las ciencias neurológicas. La finalidad principal de este artículo es reintroducir partes esenciales del texto, añadiendo comentarios sobre descripciones específicas y, como consecuencia, hacer el texto más comprensible para los científicos de hoy.

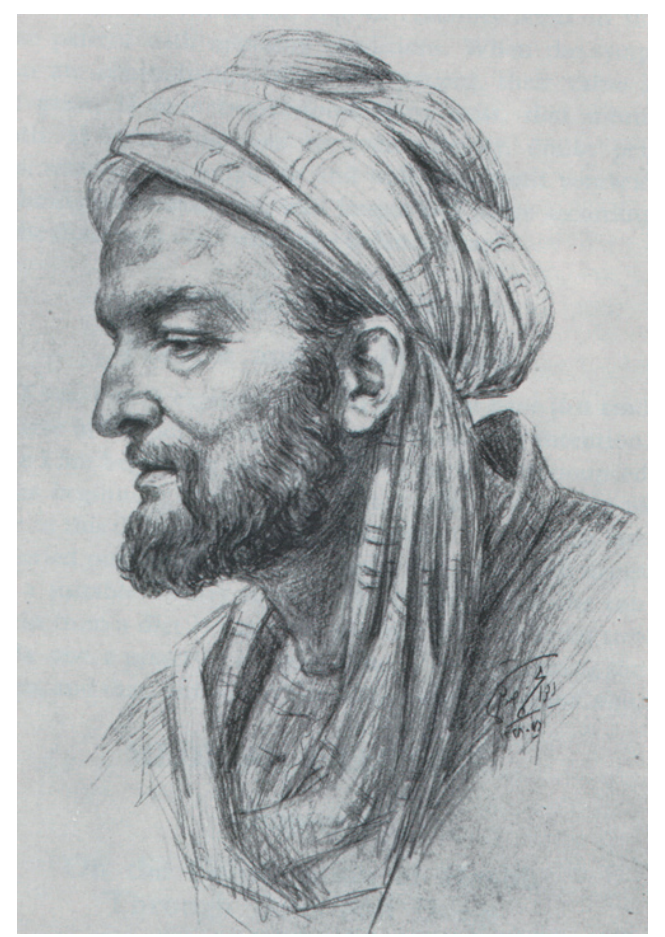

Figure 1. A portrait of Ibn Sina (Avicenna) (from, Krueger, H.C.: Avicenna's poem on medicine. Springfield, Illinois; Charles C Thomas, 1963; p 52a). 


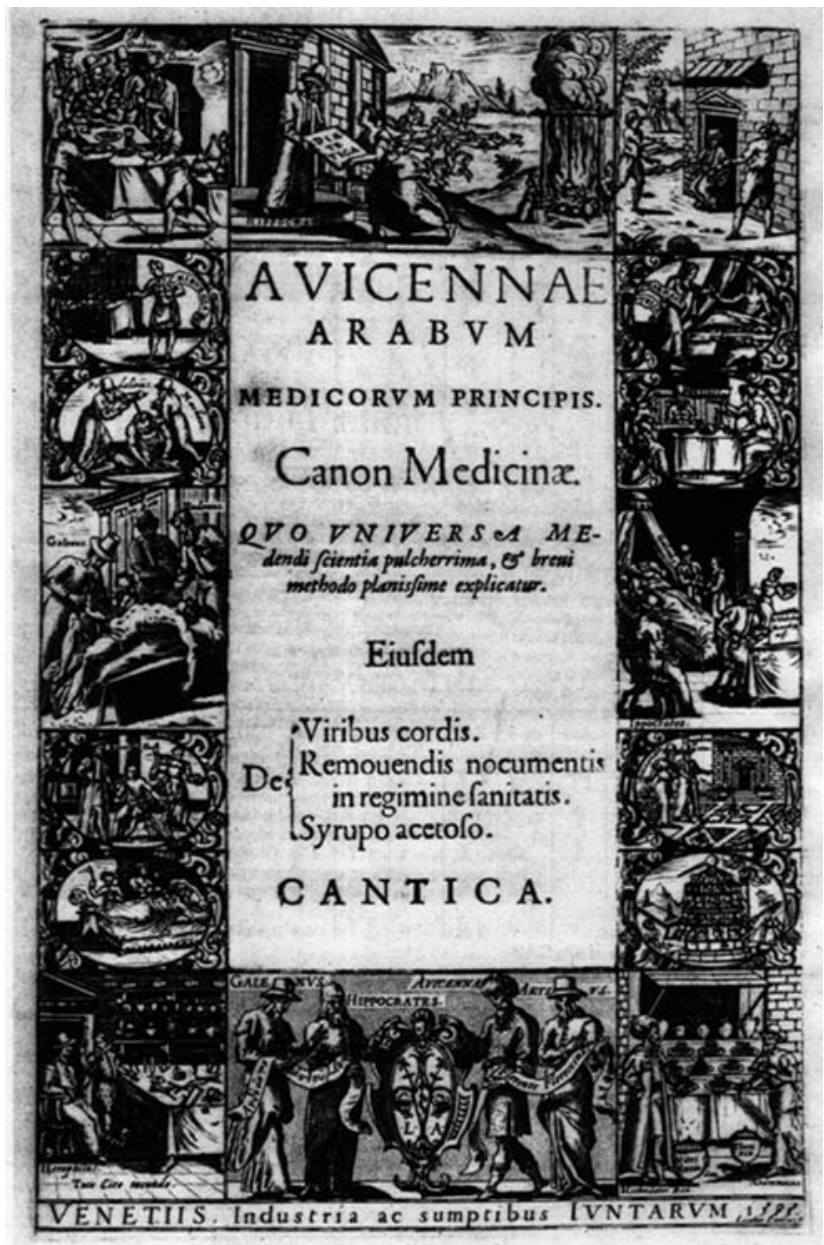

Figure 2. Frontispiece of the Latin Version of the Canon of Medicine, printed in Venice in 1595 (from, Il Canon medicinae di Avicenna nella tradizione ebraica: Le miniature del manoscritto 2197 della Biblioteca Universitaria di Bologna. A cura di Giuliano Tamani. Padova; Editoriale Programma, 1988; $p$ 21. [italian]).

PALABRAS CLAVE: Avicena. Laqve. Parálisis facial. Historia Neurocirugía.

\section{Introduction}

History of medicine indisputably resembles history of human-being. In this way, noticing the authenticity of medical historical texts and elucidating their real meaning will add valuable contribution and information to related sciences. With the present work we intended to reconsider an important historical topic introduced by Avicenna (980-1037) more than thousand years ago and tried to explain some misinterpretations regarding certain descriptions that were enthusiastically mentioned in the literature previously. Inducing of some essential parts excerpted from "Laqve" and contributing com-

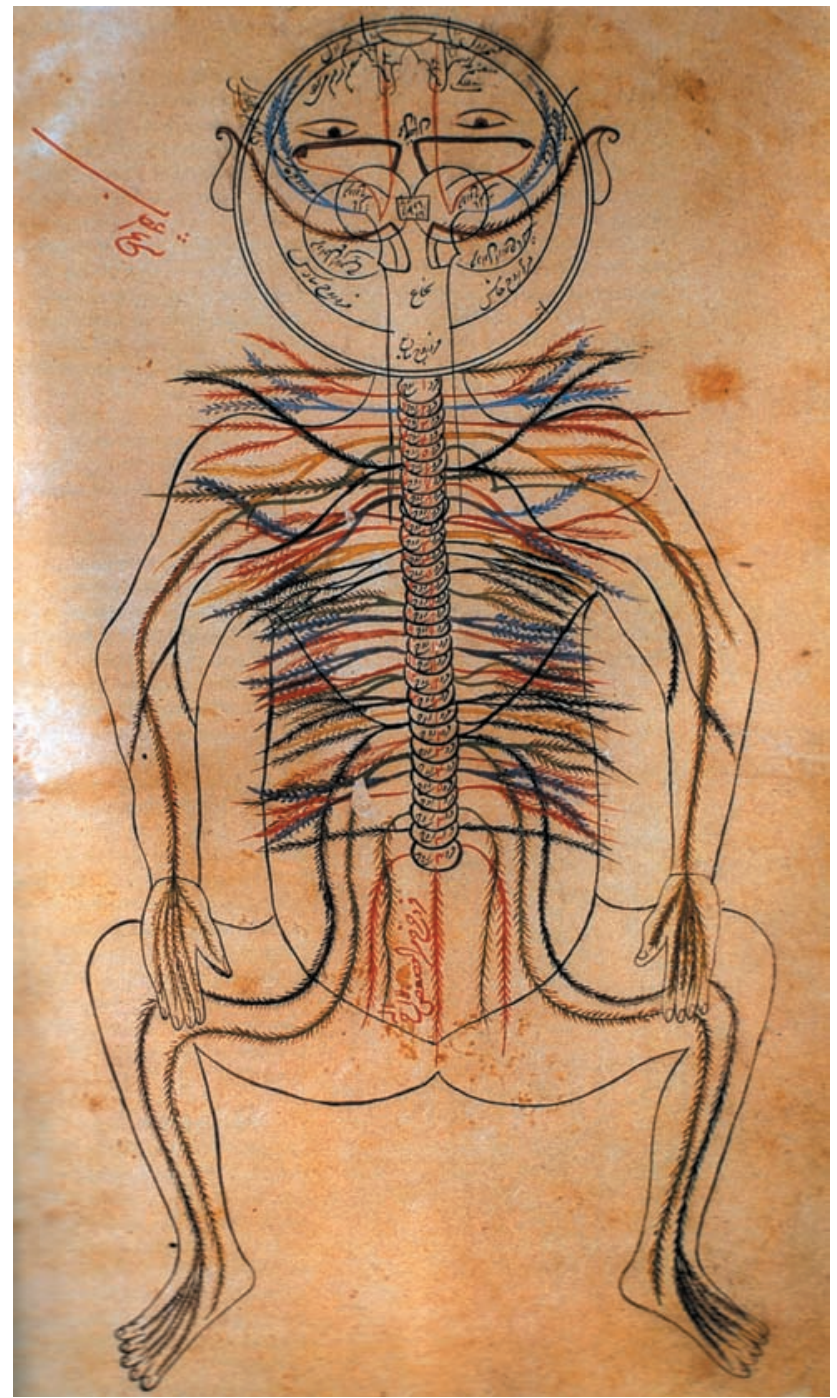

Figure 3. The schematic peripheral nervous system described in the Canon of Medicine (from Doksat M.K.: Hekimlerin piri ve hükümdar Ibn-i Sina. P "Tıp ve Sanat" 2002; 27: 56-65 [Turkish]).

ments will be the subject of this article.

As an influencing figure from medieval times, Avicenna (Fig.1) played a bridging role in the history both geographically and in episodic manner. During the medieval ages, medicine, mathematics, astronomy, physics, chemistry, geology, philosophy, theology, poetry, and also music were enriched by his invaluable works ${ }^{11}$. The ground of his medical knowledge was constructed by Hippocratic School's practice and Rhazes' experimentalism ${ }^{2}$. Avicenna's principal medical treatise the Canon was used in European universities until the late 1600s (Fig.2 and 3) ${ }^{3}$.

An interesting part from the Canon is the "Laqve", which some authors studied in detail and confidently concluded that the article is related either to "trigeminal neu- 
ralgia"1 or "facial paralysis". In reality, the term "laqve" means "paralysis and distortion of one side of the mouth or face"; thus, accepting the term only as "facial paralysis" would not be wrong. However, when the text is analyzed more carefully, further explanations and comments could be deduced.

\section{Laqve}

Laqve is a disease that involves the face. One side of face is pulled to the other side; thus, the appearance of the face changes and additionally, lips and eyelids could not be shut on the affected side.

Underlying cause of laqve is either weakness or spasm of eyelid and muscles of the face, which should be cautiously clarified by physicians.

In laqve, resulting from weakness, when one side is curved, it pulls the other side to itself and it becomes loose and changes shape. This condition usually indicates bad prognosis. Some authors including Paul [of Aegina] concluded that drooping occurs on the healthy side; however, that can not be the event.

In laqve, resulting from spasm-this is the condition encountered more frequently-the contracted side pulls the other side. When spasm is secondary to certain conditions like stern fever, diarrhea, vomiting, epistaxis, and et cetera, it is generally accepted as fatal.

As I mentioned before, some physicians have considered the affected side as the healthy part. Accordingly; they have postulated that, healthy side attempts to pull the other side for balancing facial posture, but this reflection is not always true. The knowledge derived from dissection of facial muscles may reveal the mechanisms underlying the disease. People, who are presented with multiple swellings in the muscles of neck and breathe with difficulty secondary to obstruction of airway, will also be afflicted with laqve and additionally their hands will become paralytic, due to invasion of nerves by lesions at the cervical level.

Laqve, which lasting more than six months, will not cure and it is one among the conditions difficult to treat. It is crucial to know that, laqve may precede hemiplegia secondary to cerebral bleeding and this condition is one of the frequent causes of laqve. Laqve may also be an earlier sign of epilepsy. Both situations should be diagnosed before the disease progresses to an incurable phase and an aggressive treatment is needed. Some physicians have proposed a critical time limit for laqve secondary to bleeding in the brain with which the period is described as 4 days. If the patient survives beyond this period, his/her life is most likely saved!

\section{Signs}

One of the signs, which may indicate the affected side, is hypoesthesia. Differentiation of the affected side can simply be made by following examination; when pulled, healthy side returns to its natural posture instantly, whereas affected side does not.

In weak type of laqve, saliva frequently flows out on the affected side of face. Contraction of facial muscles is weak and sensation of the affected side is diminished, and muscles and skin are softened. Half of the soft palate is droopy and wet and this sign appears with the pressure of the finger on the tongue.

In spastic type of laqve, headache may usually accompany to the condition. In many of laqve patients sensorial changes are not seen. The skin of forehead is stretched so tightly that there is no wrinkling on it. Muscles of face are stiffened and mouth water and salivation usually decrease. The sick side is pulled towards the neck. The curve of the skin towards the neck increases and it is very difficult to reverse this.

One of the significant signs of laqve is severe pain in the bones of face. Numbness in the skin or jerks and involuntary movements in the face may also be noticed in some patients.

\section{Treatment}

First of all, laqve patient should not be mobilized for a week, while some physicians offer four-day bed rest. Patients should eat excrement softening food such as chickpea juice and olive oil. If the patient has constipation, he needs softening enema on the second day.

Patience is the best way in treatment. You should use treatments that are being applied in stroke and spasm events in accordance with the condition of the patient.

For the treatment of laqve Indian physicians proposed a different method, which is wrapping the head with flesh of wild animals. The suitable tissues can be taken from rabbit, jackal, fox, male mountain-goat, deer and zebra. Since flesh of gazelle do not provide warming effect, it is useless.

If disease is spasmodic type, softening materials should be used. For that purpose, let patient drink small amount of wine, in order that the patient would not get drunk. Applying particular herbal oils on the neck is beneficial in the treatment of spasmodic type. If you see the sign of blood, cut the vein under the tongue.

It is for sure that, the matter causing weak-type laqve affects the origins of nerves supplying muscles of the face. For that reason, agents having flushing effect on the skin should be applied over cervical spine, through which region the nerve fibers travel to the neck and jaw. If drugs are useless, cauterize the vessels behind the neck!

In the case of spasmodic-type, hot topical agents should not be used, due to aggravating effect of the heat on spasm. 
I personally managed one patient, who had progressive spasmodic-type laqve. The patient had previously been treated by another physician with hot things and consequently, he had become tongue-tied. The patient had stayed in this condition for a long time. I treated him with opposite drugs and he recovered in a short period.

The patient should be trained to correct laqve through making regular massages on the face by using a mirror. For this training, smaller mirror is more useful. If a child is afflicted with laqve at the end of spring season, yellow myrobalan pasty (majoon) may be used topically and water of chickpea is given as his/her main meal during a sevenday period, he/she surely will recover ${ }^{6}$.

\section{Discussion}

Avicenna's article conveys valuable information to present-day medicine by meanings of evolution of our medical knowledge. Under contemporary neurological and neurosurgical concepts, it would not be wrong to say that laqve considers definitions of more than one disease. In fact, Avicenna analyzed laqve in two categories: 1. Weak type, and 2. Spasmodic type. While Avicenna's description "lips and eyelids could not be shot" 6 in weak type indicates idiopathic peripheral facial palsy (Bell's palsy). The account "contracting side of face pulls the other side" 6 in spasmodic type reminds us a clear definition of hemifacial spasm. In evaluation of laqve, Avicenna emphasizes the knowledge of anatomical dissection of facial structures and additionally accentuates the importance of examination: "One of the signs, which indicates the affected side, is hypoesthesia on that side"

To Avicenna the signs of weak type of laqve are facial paresis, hypoesthesia, hypotonia in the facial muscles, insensibility of lower eyelid, and relaxation of one half of the soft palate on the affected side. Current knowledge about the etiology underlying idiopathic peripheral facial palsy (Bell's palsy) emphasizes that the disease is part of a polyneuropathy syndrome induced by the herpes simplex virus; in this syndrome in addition to the facial nerve, the trigeminal nerve and as well as certain branches of the vagus nerve may be involved ${ }^{5,10}$. This statement shows considerable parallelism with those of written by Avicenna.

Avicenna's judgment about the prognosis of the disease is "Laqve, lasting more than six months, will not cure". This opinion is not much different in contemporary texts as stated for Bell's palsy ${ }^{10}$.

Avicenna describes also central facial paralysis by accepting laqve as an alarming sign of cerebrovascular accident (CVA). He additionally states that laqve can also be a preceding sign of epilepsy. It is well known that, seizure may accompany CVA that involves particular brain regions ${ }^{7,12}$. Likewise, Avicenna underlines the significance of early diagnosis and necessary intervention for CVA due to high mortality rate. Sudden death following CVA usually occurs either by cerebral edema or progressing stroke within days, which shows Avicenna's great talent over passionate observation; as his account regarding the early prognosis of CVA indicates: "patient may suddenly die in four days".

Avicenna gives also clear description of the spasmodic type of laqve with emphasizing that no sensory change is seen in this type. Indeed, this is not different from the modern definition of hemifacial spasm ${ }^{4}$. Nevertheless, Avicenna's determination about decreasing the saliva in spasmodic type of laqve shows us another accurate observation but not the true knowledge. Since chorda tympani is not involved in spasmodic type laqve, saliva secretion do not decrease and patient normally swallows them. Laqve also briefly touches to trigeminal neuralgia by the definition of "pain in the bones of the face". However, his narrative regarding accompanying symptoms to this form of laqve, such as jerks and involuntary facial movements, may indicate a description of tic convulsive.

Another appealing disorder Avicenna stresses is the mass lesions affecting the neck and causing facial and upper extremity paralysis simultaneously. We speculate that, the disease may suitably be considered as sarcoidosis because of its close resemblance clinically to tuberculosis and other granulomatous infections. The sarcoid tubercles may be found in all organs and tissues including the nervous system but most frequently involved are the mediastinal and peripheral lymph nodes, lungs, liver, skin, phalangeal bones, eyes and parotid gland. Sarcoidosis is a rare cause of subacute or chronic polyneuropathy or polyradiculopathy of assymetrical type ${ }^{13}$. Involvement of a single nerve with sarcoidosis most often takes the form of a facial palsy. In remaining cases, multiple cranial nerves are affected successively weakness, and reflex and sensory loss in the distribution of one or more spinal nerves or roots may be added ${ }^{14}$. These current accounts remind kind of granulomatous disease in the cervical region with involvement of facial and hand muscles, which Avicenna describes in detail.

In the treatment of laqve Avicenna suggests a weeklong bed rest as the first $\mathrm{step}^{6}$, most likely to differentiate whether the disease has a progressive course and whether the event is a result of CVA or not. He additionally offers excrement-softening meals with purgative medicines in order to easy evacuation of bowels ${ }^{6}$. That is a valuable therapy for preventing constipation and straining and eventually avoiding increase of intracranial pressure in the case of CVA. He further gives detailed therapeutic advises based mostly on traditional Indian medicine, which are not longer applicable like the opulent herbal medicine receipts, dressing with various animal tissues and specific surgical interventions, such as sectioning of phrenilum of the tongue ${ }^{6}$. 
Avicenna emphasizes the importance of accurate diagnosis and meticulous management of laqve by showing an illustrative case, which had previously been treated by another physician, however, was not cured ${ }^{6}$. Although, the patient recovered completely after the treatment protocol instructed by Avicenna, we could not make any comment over this particular case whether the reason for improvement was the natural course of the disease or not.

\section{Last Word}

Furtherance of knowledge has been eased by the great efforts of preceding figures who dedicated their lives to the advent of the science and technology. Avicenna was one among these influencing teachers and conveyed valuable medical and other scientific data to forthcoming generations. It obviously is impressive to see those immense similarities between current knowledge and the text 'Laqve' written by Avicenna. This work informs us about how a perfect observer Avicenna was and shows also the rational aspect of his deductions. While Avicenna considers the importance of observation, he never ignores what the paradigm has presented. Moreover, he always refers to the knowledge or experiences acquired from other medical schools, for instance the ancient Greek and Indian disciplines. Since Avicenna's treatment methods based on the paradigm stemmed from the humoral doctrine by Hippocrates, it is merely consistent with the knowledge in his time.

\section{Acknowledgement}

We thank Dt. Sehriyar Sems for his valuable contribution of translating the Persian text.

\section{References}

1. Ameli, N.O.: Avicenna and trigeminal neuralgia. J Neurol Sci 1965; 2: 105-107.

2. Gelişim Hachette Alphabetical General Culture Encyclopedia, s.v. "Ibn-i Sina".

3. Goodrich, J.T.: Landmarks in the history of neurosur- gery. In Rengechary SS, Wilkins RH (eds). Principles of Neurosurgery. London; Wolfe, 1994; pp 1.1-1.25.

4. Haerer, A.F.: DeJong's the neurological examination, $5^{\text {th }}$ ed. Philadelphia; J.B. Lippincott Company, 1992; p 197.

5. Haerer, A.F.: DeJong's the neurological examination, $5^{\text {th }}$ ed. Philadelphia; J.B. Lippincott Company, 1992; p 235.

6. Ibn Sina: [The Canon of Medicine], (Sharafkandi A, trans.), [in Persian]. Tehran; Soroush Press, 1997; Vol 3, Part 1, pp 190-193.

7. Kaufmann, H.H.: Spontaneous intraparanchymal brain hemorrhage: In Wilkins RH, Rengachary SS (eds). Neurosurgery, $2^{\text {nd }}$ ed. New York; Mc Graw-Hill Companies, 1996; Vol 2, pp 2567-2585.

8. Preul, M.C.: Historical considerations of the diagnosis and treatment of facial pain. Neurosurg Clin North Am 2001; 12 (1): 111-126.

9. Redhouse, J.W.: A Turkish and English lexicon. Beirut; Librarie du Liban (New Impression), 1996; p 1638.

10. Rengacahary, S.S.: Cranial nerve examination. In Wilkins RH, Rengachary SS (eds). Neurosurgery, $2^{\text {nd }}$ ed. New York; Mc Graw-Hill Companies, 1996; Vol 1, pp 67-85.

11. Robinson, V.: The story of medicine. New York; The New Home Library, August 1943, reprinted 1944; pp 160164.

12. Sherman, D.G., Easton, J.D.: Clinical syndromes of brain ischemia. In Wilkins RH, Rengachary SS (eds). Neurosurgery, $2^{\text {nd }}$ ed. New York; Mc Graw-Hill Companies, 1996; Vol 2, pp 2045-2065.

13. Victor, M., Ropper, A.H.: Adams and Victor's principles of neurology, $7^{\text {th }}$ ed. New York; Mc Graw-Hill Companies, 2001; p 760.

14. Victor, M., Ropper, A.H.: Adams and Victor's principles of neurology, $7^{\text {th }}$ ed. New York; Mc Graw-Hill Companies, 2001; pp 1402-1403

Aciduman, A.; Arda, B.; Gunaydin, A.; Belen, D.: Laqve (wry mouth) considered in Avicenna's renowned treatise the canon of medicine. Neurocirugía 2008; 19: 267-271.

Corresponding author: Ahmet Aciduman. Dögol Caddesi, No: 27-14, Mebusevleri, 06580 Ankara. Turkey. 